RESPONSE

\title{
What If There Is Life on Other Planets? Reflections on Kurt Cardinal Koch's Inaugural Lecture
}

\author{
Jesper Svartvik ${ }^{1}$, Lund University and the
} Swedish Theological Institute in Jerusalem

\author{
A Response to Cardinal Kurt Koch's October 30, 2011 Keynote Address \\ at Seton Hall University during the $10^{\text {th }}$ Annual Meeting of the \\ Council of Centers on Christian-Jewish Relations
}

Towards the end of 2011 , the media reported on the recently discovered planet Kepler 22b, where conditions were such that it was not beyond the realm of possibility that life might exist. When reading about this discovery, we find ourselves wondering: what if there is life on other planets? If the inhabitants are anything like us, what are their personalities, their history, their cultures, their religions, etc.? That there may be life on other planets is a staggering thought, but the opposite is also staggering: what if there is no life in the universe except here on our planet? What if we are completely alone in the entire universe?

My thoughts went to the news about Kepler 22b when invited to comment on Kurt Cardinal Koch's inaugural lecture on Jewish-Christian relations, given at Seton Hall University in South Orange, New Jersey: "Theological Questions and Perspectives in Jewish-Catholic Dialogue". Needless to say, I am deeply honoured and most grateful for this opportunity to comment on his lecture in the journal Studies in Christian-Jewish Relations. Due to considerations of space, I will have to limit myself to ten brief comments on his rich and thought-provoking lecture. It is impossible to address here the whole panoply of issues in his address.

\section{Jews and Christians Divided by a Common Language}

Cardinal Koch begins by pointing out the duality that characterizes Jewish-Christian relations: there is both nearness and distance, kinship and alienation, affection and loathing. Jesus cannot be understood outside of Second-Temple Judaism, and Christianity cannot be understood without Judaism. He points out that the schism between what we today call "Judaism" and "Christianity" actually took far longer to develop than the scholarly world previously assumed: the gradual parting of the ways probably extended over hundreds of years. He uses Erich Przywara's helpful concept of "the primal rift" to describe the relationship, and it is an apt description. We find this discourse of gradual separation already in the New Testament, e.g., in the Gospel of John.

\footnotetext{
${ }^{1}$ This is a translated and revised version of a public lecture given in the auditorium at Lund University on December 16, 2011. Heartfelt thanks are due to Raymond Cohen, Tamara Cohn Eskenazi, Göran Larsson, Inger Nebel, Michael Swirsky, Thaddeus Umaru, and Jakob Wirén for stimulating conversations and helpful comments. In addition, I would also like to thank Michael Swirsky for correcting and improving my English.

${ }^{2}$ The Cardinal had previously given this lecture three days earlier, but in Europe and in German. His lecture at Seton Hall University was the eighteenth annual Monsignor John M. Oesterreicher Memorial Lecture.
} 
Not surprisingly, the Cardinal quotes John Paul Il's well-known address at the Great Synagogue in Rome on April 13, 1986. In this speech the Pope stated that the Jewish faith tradition's relation to Christianity is not extrinsic but intrinsic; it does not come from outside but from within.

Differently expressed, with the help of a narrative, when Christians come to the classroom to study interreligious relations and are preparing to invite a Muslim, a Hindu, a Buddhist, and a Jew for conversation, they suddenly realize that the Jewish representative is already there, that he was there even before the Christians entered the room, reading the holy texts of the Christian tradition in the original Hebrew. It remains imperative to recall the words of John Paul II on the dialogue: "With Judaism we therefore have a relationship we do not have with any other religion."

At the same time, however, the Jewish-Christian relationship is always pointing beyond itself. The Christian interreligious conversation starts there, but it does not end there. This is particularly apparent in the document "A Sacred Obligation: Rethinking Christian Faith in Relation to Judaism and the Jewish People," published on September 1, 2002. Its sixth paragraph reads:

Affirming God's enduring covenant with the Jewish people has consequences for Christian understanding of salvation. Christians meet God's saving power in the person of Jesus Christ and believe that this power is available to all people in him. Christians have therefore taught for centuries that salvation is available only through Jesus Christ. With their recent realization that God's covenant with the Jewish people is eternal, Christians can now recognize in the Jewish tradition the redemptive power of God at work. If Jews, who do not share our faith in Christ, are in a saving covenant with God, then Christians need new ways of understanding the universal significance of Christ. ${ }^{3}$

In other words, what would be the consequences for other interreligious relations if this notion were accepted in the Jewish-Christian encounter? There is more here than meets the eye, more at stake than we might at first think. Even when the focus is on Jewish-Christian relations, we may also discern there-between the lines, so to speak-the attitude of the Roman Catholic Church towards Muslims, Hindus, Buddhists, and others. Cardinal Koch is responsible for innerChristian and Jewish-Christian relations. In spite of the fact that Judaism is patently nonChristological in its hermeneutics, soteriology, and liturgy, it is almost seen as part of the ecumenical family. Following George Bernard Shaw's well-known quip about Britain and America, we might say that Jews and Christians are two nations divided by a common language. ${ }^{4}$ In a nutshell, it is the similarities that define the particularity.

\section{The Shoah and Christendom}

No programmatic lecture on Jewish-Christian relations by a Roman Catholic cardinal can avoid the topic of the Shoah. The fact that the Shoah took place on the continent that more than any other has been influenced by Christian teaching and preaching is the reason for the theological self-examination that Christians throughout the world must undertake: what in Christian nomenclature and doctrine may have contributed to the agonizing fact that, when the bells tolled, so many Christians were lacking in common decency?

\footnotetext{
${ }^{3}$ Mary Boys (ed.), Seeing Judaism Anew: Christianity's Sacred Obligation (Lanham et alii loci: Rowman \& Littlefield, 2005), xvi.

${ }^{4}$ The statement is attributed to a number of persons, e.g., Oscar Wilde, Dylan Thomas and Bertrand Russell.
} 
Already in the documents that deal with these issues-above all, I am here thinking of "We Remember: A Reflection on the Shoah", presented on March 16, 1998 by Edward Cardinal Cassidy - we may identify three arguments in the Roman Catholic discourse:

(a) First, Nazism was a godless, anti-Christian and neo-pagan movement. Eventually, Nazi hatred of Jews and Judaism would have turned against Christianity in a similar way. Cardinal Koch refers to the diaries of Goebbels that, he argues, show that Hitler hated Christianity as much as Judaism. Hitler saw Catholicism as a Trojan horse that had brought Judaism in.

(b) Second, as is customary, Cardinal Koch distinguishes between Christianity and Christians, between the Church, on the one hand, and the sons and daughters of the Church, on the other. It should be made clear, however, that whenever the category "the sons and daughters of the Church" is used in the discussion, it actually also includes the leaders of the Church. They, too, are the sons of the Church. It is, in fact, primarily from the pulpits, not by the men and women in the pew, that "the teaching of contempt" has been spread throughout the ages. There is a risk that the expression "the sons and daughters of the Church" may lead us to think that it is only the laity who have been influenced by and have given vent to anti-Jewish teaching.

(c) The third point is the distinction between the racist antisemitism of Nazism, on the one hand, and distinctively Christian anti-Judaism on the other. My own take on this is that since there are more than these two forms of what Helen Fein calls "a persisting latent structure of hostile beliefs towards Jews as a collectivity," we need to draw further distinctions. ${ }^{5}$ Nevertheless, we should also take into consideration the fact that the limpieza de sangre controversy in Spain after 1492 took place in a Christian context, not in a secular, post-Christian, or anti-Christian milieu. ${ }^{6}$ Hence, the distinction between antisemitism and anti-Judaism should not be used as a basis for the claim that the roots of antisemitism are to be found exclusively outside of Christendom.

Having presented these three points (i.e., the godlessness of Nazism; the dichotomy of Church versus the sons and daughters of the Church, and the essential difference between antisemitism and anti-Judaism), Cardinal Koch emphasizes that Christians have every reason to remember how they encouraged and even participated in the terrible developments that culminated in the Holocaust. He sees the Shoah as a turning point in Christian theological reflection, although we are not told what this change consisted of: it would have been most helpful if he had explained more clearly what parts of their discourse Christians now felt a need to refine, redefine, and also refute. He concludes with what may seem like a daring idea: the fact that Hitler was opposed to both Christianity and Judaism implies an "intrinsic relationship" between the two faith traditions. The question has to be posed, however, whether the rhetorical benefit of this statement is not outweighed by its theological costs. Unfortunately, it is easy to get the impression that Koch somehow equates Jewish and Christian suffering during the Third Reich era. By any standard, antisemitism played a far more central role in Nazi ideology than the animus toward Christianity. ${ }^{7}$

\footnotetext{
${ }^{5}$ Helen Fein, "Dimensions of Antisemitism: Attitudes, Collective Accusations, and Actions," The Persisting Question: Sociological Perspectives and Social Contexts of Modern Antisemitism (ed. Helen Fein; Berlin / New York: Walter de Gruyter, 1987), 67.

${ }^{6}$ See, e.g., George M. Fredrickson, Racism: A Short History (Princeton: Princeton University Press, 2002$), 32$.

${ }^{7}$ See, e.g., Doris L. Bergen, Twisted Cross: The German Christian Movement in the Third Reich (Chapel Hill / London: University of North Carolina, 1996).
} 


\section{Liberal Christianity and Jewish-Christian Relations}

An important and helpful remark in Koch's presentation is that there are problems not only in what he calls the "traditionalist" theological context; liberal Christians, too, need to reflect on the relationship between Jesus and the people of Jesus, between early Christianity and contemporary Second-Temple Judaism. Liberals tend to use the tensions between Jesus and some of his contemporaries as the basis for a critique of Judaism itself, as a religion that weighs people down with ritual commandments, and that Jesus freed men and women from these outdated and useless encumbrances. However, the Cardinal's point is weakened somewhat by his choice of words: unfortunately and remarkably, he describes the conflict as one between Jesus and "the Judaism of his days" [sic], which is not very far removed from the very dichotomy that he criticizes.

Nevertheless, he has an important point. Far too often the essentially inner-Christian selfcriticism of liberal Christianity mutates into anti-Jewish criticism, so that Jesus' historical context is presented as one of theological conflict. Jesus is then deprived of his Jewishness. He becomes a gentile in a foreign country, surrounded by hostile Jews. Ultimately, such a presentation of the protagonist in the New Testament constitutes a threat to the Christian doctrine of incarnation. Leo Baeck's admonition is still valid: "Man muss die Juden kennen, wenn man das Evangelium verstehen will."8

\section{Scriptural Hermeneutics}

The Cardinal also discusses how Jews and Christians interpret their Holy Scriptures. How do the two parts of the Christian Bible relate to each other? Interestingly, he describes Marcion's theology using the images of the moon and the sun: the Jewish moon is replaced by the Christian sun. But is it really Marcionism that is best described by the sun and moon metaphors? Is it not rather anti-Marcionite, mainstream Christian theology that should be described thus? Marcion's understanding was that there actually was a Jewish light but that it would be wrong to follow it. A more accurate metaphor for Marcion's view would be that the New Testament is a lighthouse that may be relied on to guide ships at sea, while the light of the Jewish Scriptures must not be mistaken for a beacon. Unlike the moon, it does not illuminate, but rather distracts and diverts us.

Going back to the Cardinal's sun-and-moon illustration, we need to keep in mind that it is not the moon itself that shines; it simply reflects light from the sun. Intriguingly, his sun-and-moon analogy fits the supersessionist theology of the Church Fathers much more than the theology of Marcion. A number of the patres would argue that it is Christocentric hermeneutics that make the Old Testament worth reading. The latter is like the moon that shines at night only because it reflects the sun, i.e., the Christ of the Church. Nonetheless, it is difficult to determine Koch's intention here. This picture, too, seems to detract more than it adds.

After a discussion of traditional models for the relationship between the Old and New Testaments and between Judaism and Christianity, Koch stresses that Rabbinic Judaism and Christianity are both responses to the fall of the Temple. Referring to Pope Benedict XVI, he states that "two new ways of reading the Old Testament [emerged] after the year 70"-an important statement. He goes on to propose that Jews and Christians should initiate a dialogue on scriptural hermeneutics in order to better understand God's Word and God's will. He refers to the text "The Jewish People and their Sacred Scriptures in the Christian Bible" and underlines what

\footnotetext{
${ }^{8}$ Leo Baeck, Harnacks Vorlesungen über das Wesen des Christentums (Breslau: Koebner, 1902), 28.
} 
has already been established there: "...the Jewish reading of the Bible is a possible one" and "...both [readings] are irreducible."

How, then, are the relations between the two faith communities and the two parts of the Christian Bible best understood? It is not, he says, a question of annulment or replacement, but rather of fulfillment. The obvious question is what this actually means: what does this particular consummatum est imply? Is it not true that many Christians mean annulment and replacement when they say fulfillment? Can fulfillment really be imagined without some sort of annulment and/or replacement? What does fulfillment look like? What do Christians mean when they use this term? And in what way does the sun-and-moon metaphor contribute to the discussion? This section of his lecture is one of the most constructive and helpful in the entire lecture, but there is nevertheless more to be said if we are to avoid what might be called a "comparative hermeneutics" in which one religious tradition is presented as fulfilling the other.

\section{One People or Two Peoples?}

A central section of Cardinal Koch's lecture is the discussion of the concept of God's people: how should the Jewish people and the Christian church be described? Is there one such people or two? He quotes with approval an article written by Gregor Maria Hoff in the recently published anthology Christ Jesus and the Jewish People: New Explorations of Theological Interrelationships. Hoff argues that Judaism and Christianity are "inseparable and distinct." "Those who know their Church history instantly recognize that behind this expression lies the discussion of Christ's nature(s) at the Council of Chalcedon. The question of whether Jews and Christians are one people or two is answered by different groups in different ways.

(a) Is only the Church God's people? For a long time, this was the only conceivable answer for Christians. Although the Cardinal quotes a Protestant theologian, Paul Althaus, I would guess that he could have cited a Roman Catholic theologian as well, had he chosen to do so. Indeed, one might argue that it would have been more appropriate in this context to quote someone from the Roman Catholic tradition. As we all know, Christian supersessionism is hardly a late phenomenon and in no way an exclusively Protestant one.

(b) What if only Israel is God's people? This view is probably most common among Christians who are strongly committed to the Jewish people and also to the State of Israel. The problem is that some of those who adhere to this position seem to be completely indifferent to the plight of their sisters and brothers in Christ in the Middle East. ${ }^{10} \mathrm{I}$ do not mean that Christians should be committed only to Christians, but the problem with this position becomes particularly apparent when Christian pilgrims come to visit Israel but not the Palestinian territories and when they celebrate the Jewish Feast of Tabernacles but do not worship with their Christian sisters and

\footnotetext{
${ }^{9}$ Gregor Maria Hoff, "A Realm of Differences: The Meaning of Jewish Monotheism for Christology and Trinitarian Theology," Christ Jesus and the Jewish People Today: New Explorations of Theological Interrelationships (eds. Philip A. Cunningham et alii; Grand Rapids / Cambridge: Eerdmans, 2011), 218.

${ }^{10}$ For a presentation of Arab Christians, see, e.g., Kenneth Cragg, The Arab Christian: A History in the Middle East (London: Mowbray, 1992) and Betty Jane Bailey \& J. Martin Bailey, Who Are the Christians in the Middle East? (Grand Rapids / Cambridge: Eerdmans, $2^{\text {nd }}$ ed. 2010). For the predicament of Palestinian Christians, see, e.g., Rifat Odeh Kassis, Kairos for Palestine (Ramallah: Baydal/Alternatives, 2011). See also Jean Corbon, "Middle East," A History of the Ecumenical Movement (eds. John Briggs, Mercy Amba Oduyoye \& Georges Tsetsis; Geneva: World Council of Churches, 2004), 591-608.
} 
brothers. ${ }^{11}$ I have a distressing feeling that the concept of "God's people" contributes to this theological myopia.

(c) Is the answer, then, that there are two peoples of God, i.e., the Jews and the Christians? Cardinal Koch strongly emphasizes that there can only be one people. We will return to this point in the discussion below on soteriology.

(d) Since the people-of-God discourse is inherently problematical, I have in various contexts (e.g., a conference hosted by World Council of Churches in Bern in 2008 and a consultation in Istanbul in 2010, and also at the Faith and Order consultations in Zürich in 2006 and in Copenhagen in 2011, etc.) proposed that Christians instead use the Corpus Christi discourse, i.e., that Christians think of themselves as the visible presence of Christ in this world. It is a metaphor with ancient roots (it can be found in some of the Pauline epistles), it is Christocentric (Christ being the head), it encourages Christians to celebrate diversity (we are likened to different parts of the body, members that are all needed in different ways), and it does not come at the expense of other religious communities (as there is no other faith community that thinks of itself and calls itself the Corpus Christi).

\section{Soteriological Discourse}

Soteriology is never far away in the Jewish-Christian dialogue-when Christians have the floor. In his speech the Cardinal maintains that God has never revoked the covenant with Israel, a remarkable statement first made by John Paul II, probably in Mainz in 1980, when he referred to: "... the people of God of the old covenant, which has never been revoked by God". ${ }^{12}$ Nevertheless, the Cardinal emphasizes that there cannot be two ways to salvation:

The assumption that there may be two different paths to salvation...would in fact also endanger the foundations of Christian faith. [...] From the Christian confession that there can be only one path to salvation; however, it does not in any way follow that the Jews are excluded from God's salvation because they do not believe in Jesus Christ as the Messiah of Israel and the Son of God. [...] That the Jews are participants in God's salvation is theologically unquestionable, but how that can be possible without confessing Christ explicitly is and remains an unfathomable divine mystery.

He thus poses the question of how the two faith traditions are related to each other-and responds by referring to a divine mystery. One is inclined to ask whether more could not be said on this matter. It is easy to get the impression that Koch is positive about the answer but disapproves of its rationale; that he appreciates the solution, but objects to the arguments supporting it. In a nutshell, he wants the gate to be unlocked, but he does not want the key to be used.

The latter metaphor takes us to Romans 9-11, which is certainly the key passage in the New Testament for Jewish-Christian relations. This point is made by Eugene J. Fisher, among others, in his article on "Nostra Aetate" in A Dictionary of Jewish-Christian Relations. Stressing the importance of this 1965 document, he states that "[i]t is easily the most significant document

\footnotetext{
${ }^{11}$ For statistics, see, e.g., Victoria Clark, Allies for Armageddon: The Rise of Christian Zionism (New Haven / London: Yale University Press), 230.

${ }^{12}$ See, e.g., Norbert Lohfink, The Covenant Never Revoked: Biblical Reflections on Christian-Jewish Dialogue (New York / Mahwah: Paulist Press, 1991), 5.
} 
concerning Jewish-Christian relations in Church history since Paul in Romans 9-11." ${ }^{13}$ This statement by Fisher says a lot about the tremendous importance both of the documents of the Second Vatican Council and of the three chapters in the Pauline epistle.

The Cardinal then refers to the Pauline discussion of the Romans, noting that Paul ends the eleventh chapter with a doxology. Krister Stendahl often pointed out that the discourse of this doxology is theocentric; when Paul in this paragraph, in what we argue is the key passage for Jewish-Christian relations, concludes by praising God, he does so with a non-Christological doxology. ${ }^{14}$ To what extent do we allow this observation to inform Christian theology? Does it tell us something about the direction we should take in seeking answers to these questions? Cardinal Koch also writes the following:

The focus of Jewish-Christian conversations must therefore remain the highly complex theological questions of how the Christian belief in the universal salvific significance of Jesus Christ can coherently be conceptually combined with the equally clear statement of faith in the never-revoked covenant of God with Israel.

But is the need for such a focus indisputable? Is this really the only possible agenda for JewishChristian relations? What do Jews think and say about this? Are there not other issues to discuss as well? Raymond Cohen has pointed out that, strictly speaking, Nostra Aetate is not a dialogical document; it is an inner-Christian text that seeks to distance the Church from its own triumphalistic theology of earlier times. ${ }^{15}$ I would therefore like to rephrase the Cardinal's statement: Christian reflection should continue to focus on the highly complex theological questions of how Christian belief in the universal salvific significance of Jesus Christ can cohere conceptually with an equally clear belief in the never-revoked covenant of God with Israel.

It is right and proper for Christians to do such reflection-but it need not necessarily be on the agenda of Jewish-Christian dialogue. Instead, Jews and Christian may discuss other important issues, e.g., Jewish and Christian scriptural hermeneutics, the question of how to be faithful to one's vocation in a secular society, etc.

\section{The Issue of Mission}

Cardinal Koch points out that the Roman Catholic Church-in contrast to many other Christian denominations-does not make organized efforts to convert Jews to Christianity. He refers to Karl Lehmann, who points out that even in the past there were few such Catholic efforts. Here the Augustinian heritage is quite evident: there is a role for Jews and Judaism to play also post Christum. ${ }^{16}$ But having said this, the Cardinal continues:

...the Christian church is obligated to perceive its evangelization task in respect of the Jews, who believe in the one God, in a different manner from that to the nations.

\footnotetext{
${ }^{13}$ Eugene J. Fisher, "Nostra Aetate," A Dictionary of Jewish-Christian Relations (eds. Edward Kessler \& Neil Wenborn; Cambridge: Cambridge University Press, 2005), 320.

${ }^{14}$ See, e.g., Krister Stendahl, Final Account: Paul's Letter to the Romans (Minneapolis: Fortress, 1995), 7: “... he wrote a doxology, the only doxology Paul ever wrote in God-language, without any mention of Christ or Jesus."

${ }^{15}$ Raymond Cohen, "Catholic-Jewish Reconciliation: From Theology to Diplomacy," Do I Know You? Religious Stereotyping and Interreligious Relations (eds. Jesper Svartvik \& Jakob Wirén; forthcoming 2012).

${ }^{16}$ See, e.g., James Carroll, Constantine's Sword: The Church and the Jews (Boston / New York: Houghton Mifflin, 2001), 208-219, and Paula Fredriksen, Augustine and the Jews: A Christian Defense of Jews and Judaism (New York: Doubleday et alii loci, 2008).
} 
In other words, Christian faith means something different for Jews than for others. In the language of John Paul II, this has to do with the intrinsic (as opposed to extrinsic) relationship between Jews and Christians: through their texts (the so-called "Old Testament"), tradition (Church history), and trust (in the God who is revealed in these texts and in the tradition), Jews and Christians are forever united. However, the Cardinal points out, Catholics will not let this prevent them from testifying about their Christian faith:

...from bearing witness to their faith in Jesus Christ also to Jews, but [they] should do so in a humble and unassuming manner, particularly in view of the great tragedy of the Shoah...

But he says nothing about how the Shoah should influence-or even shape-the JewishChristian relationship. Is it only a question of how to convey the message-or is it rather a question of reviewing the message itself, in order to make sure that it is "humble and unassuming"? If the latter answer is to be preferred, the work has only begun.

I, for one, would have preferred that the Cardinal be clearer in this passage of his lecture, because it has major implications. He could, for example, have referred to the advice given in 1 Peter 3:15: "Always be prepared to make a defense to anyone who calls you to account for the hope that is in you, yet do it with gentleness and reverence." There is a tremendous difference between, on one hand, responding when someone wants to know more about your faith and, on the other hand, providing answers even when questions have not been posed.

\section{The Cross as a Sacrament of Reconciliation}

Towards the end of his lecture, Cardinal Koch discusses the cross, more in terms of what it symbolizes than as a historical event:

Because the cross of Jesus Christ has again and again in the course of Christian history been misused as an anti-sign of hostility and hatred towards the Jews by condemning them as deicides, Christians today have every reason and a strict obligation to proclaim and testify also to the Jews the cross of Jesus as a sacrament of reconciliation.

First of all, we need to keep in mind that there is no Christian symbol that makes Jews feel as uneasy as the cross, especially if it is a crucifix. ${ }^{17}$ Therefore, it is highly relevant to ask how the cross can serve as "a sacrament of reconciliation." I often think of the Pauline expression in 2 Cor 5:19, where the Apostle states that Christians are called to proclaim "the word of reconciliation" (Greek: ho logos tês katallagês). This is often translated as "the word about the reconciliation" (i.e., with an emphasis on the proclamation per se), but it could also be understood as "the word that is reconciliation," the word that brings about and accomplishes reconciliation (i.e., with an emphasis on the outcome). In other words, in what way can Christians promote reconciliation in this world?

Cardinal Koch writes that the cross must be a sign and a tool for reconciliation in the world. It is easy to understand that it is a sign-for Christians, that is-of reconciliation, but how will it become a tool for reconciliation with non-Christians, especially Jews? The sacramental discourse is exceptionally powerful, but it might not always be helpful when discussing the cross as a

\footnotetext{
${ }^{17}$ See, e.g., Ruth Langer, "Liturgy and Sensory Experience," Christianity in Jewish Terms (eds. Tikva Frymer-Kensky
} et alii; Boulder: Westview, 2000), 193. 
historical event or a symbol: the notion of a sacrament being effective ex opere operato can blind Christians to the uneasiness that many Jews feel when confronted, whether visually or theologically, with the cross. There is more to say here. Suffice it now to state that much work remains to be done.

\section{Revelation and Particularity}

Finally, something ought to be said about the lecture's concluding passage, which, in the view of the present writer, is the most important part of it:

That even after a "complex and not infrequently painful" history reconciliation can be and indeed is possible, that is attested by the Jewish-Christian dialogue over the past decades, and this is a sign of hope for continuing the pilgrim fellowship of reconciliation in faith in the shechina of God in the Torah and in the incarnation of God in Jesus Christ.

The passage is significant in that: (a) it acknowledges that Jewish-Christian relations have historically been very bad; (b) it refers to the motif of pilgrimage (i.e., that we are all on our way); and most importantly, (c) it describes the religious Other using the latter's own nomenclature. In other words, Koch allows the religious Others to define themselves. To speak about "salvation in Jesus" and to refer to Pauline texts is and will remain important in Christian discourse, but if we really want to understand the Others and allow them to define themselves, we must describe them in ways that they themselves find recognizable. Cardinal Koch does this in an earlier passage in the article:

If Christian theology succeeds in credibly demonstrating that the incarnation of God in Jesus of Nazareth is to be understood as the culmination point and fulfilment of the selfrevealing God of Holy Scripture who turns towards the world, condescends into history and engages in it, Jews for their part could perceive God's self-exposition in bestowing the Torah and in sending the Shechina to the people of Israel as anticipations of what the Christian faith was to develop in the doctrine of the Trinity.

Christians speak about the revelation that they know and have experienced, i.e., incarnational theology; Jews talk about what is central to their belief, the Torah. My own experience is that of all questions that we can pose in interreligious dialogue, there is none that generates trust as effectively as the following question: "According to your tradition, how does God reveal Godself?" This is exactly what the Cardinal does when he utilizes what I would like to call the dual theological epistemology to speak about the mystery of Incarnation for Christians and the Shekhinah (i.e., the divine presence) in the Torah for Jews. In certain senses, Jesus Christ is to the Christian Church what the Torah is to the Jewish people. ${ }^{18}$

It is in this context that the words of the Johannine Prologue should be understood: "The Word...resided [Greek: eskênôsen; "tabernacled"] among us, and we saw its glory...filled with mercy and truth." The difference between Jews and Christians is not over the belief that the Word is present among us human beings; the difference is that it is the Torah that Jews

\footnotetext{
${ }^{18}$ A particular radical formulation is "Just as early Christian exegetes saw in Christ God made flesh, so the rabbis conceived of the Torah as the incarnation of the image of God," see Elliot R. Wolfson, "Judaism and Incarnation: The Imaginal Body of God", Christianity in Jewish Terms (eds. Tikva Frymer-Kensky et alii; Boulder: Westview, 2000$), 247$. See also Norman Lamm, Torah Lishmah: Torah for Torah's Sake in the Works of Rabbi Hayyim of Volozhin and his Contemporaries (New York / Hoboken: Yeshiva University Press / Ktav, 1989), 103f.: "In that case, Torah is a direct facet of God, and in it and through it one can experience God's presence immediately and without interference. Torah is then, in a sense, part of God Himself rather than the product of His will ..."
} 
spontaneously think of as the Word. Similarly, the Talmudic statement dibra Torah bilshon benei adam ("the Torah speaks the language of human beings") is intriguingly analogous to the statement that Jesus of Nazareth is totum Verbum, sed non totum Verbi. ${ }^{19}$

The difference between the understanding of the Torah and of Jesus of Nazareth should not obscure the fact that the two traditions-in this very sense-are both revelational. ${ }^{20}$ It is true that there is no rabbinical dogma of divine presence that goes as far as the Christological discourse within Christianity, but there can be no doubt that both traditions proclaim that God reveals Godself, and that God dwells ("tabernacles") among us (see, e.g., Ex 25:8).

\section{Continuing Challenges}

Finally, something ought to be said also about what Eric Greenberg calls "the continuing challenges facing Catholic-Jewish relations." ${ }^{21}$ (a) First, it would have been advantageous to hear more about the Jewish perspective on the dialogue. It has already been mentioned that Cardinal Koch's references to the Shekhinah and the Torah are helpful-they prove that he is eager to understand the other religious tradition-but he could have made this point in other ways as well, e.g., in his discussion of Scriptural hermeneutics. To be sure, he refers to Jacob Neusner (presented as a rabbi, although to the scholarly world he is known as a distinguished professor), but Neusner is hardly a leading practitioner of Jewish-Christian dialogue. The Cardinal could have referred to Jewish theologians who have as much, if not more, experience in the field of JewishChristian relations, e.g., Edward Kessler, Ruth Langer, Michael Signer, and Deborah Weissman. $^{22}$ (b) Secondly, how is one's own theology influenced by the presence of the Other? Cardinal Koch describes Jews and Christians as thorns in each other's sides, which is not a reference to the crucifixion (although some who have commented on his speech seem to be under that impression) but to a Pauline statement in which he says he has "a thorn in the flesh" (2 Cor 12:7). Referring to the religious Other as "a thorn in the flesh" (what Paul calls "an angel of Satan") is certainly suggestive, especially given that its purpose is a positive one: "... to keep [Paul]...from being made too haughty by the abundance of revelations [that he has received]"; but might there not be more conciliatory, enriching, or constructive metaphors to use? Some kind of thorn tormented Paul, but thanks to the grace of God it was possible for him to prevail over it. What good can such a metaphor do? Is this really what we want to say about the religious Other? Is it only because of divine grace, which "...is sufficient for you, my power [being] made perfect in weakness," that we are able to tolerate the religious Other? ${ }^{23}$ Several metaphors are used in discussions of interreligious relations: is the religious Other my enemy to be combated; an acquaintance, whom I greet when we meet a few times a year; a friend to whom I come in difficult times; or perhaps a relative, to whom I am forever related? The question is whether the sibling metaphor is the most accurate and viable one. Siblings are related to each other because

\footnotetext{
${ }^{19}$ Nedarim 3 a and Christianismus et religiones 1.5 (21).

${ }^{20}$ See, e.g., Carroll, Constantine's Sword, 106: "How is God present to the world, not in the abstract but in the concrete, which is the only meaning 'present' can have? As a Christian believer answers 'in Jesus,' and a Muslim 'in the Koran' (not Muhammad), so a Jewish believer today might answer, 'through Torah.' [...] Following a tradition that begins with the Temple, all three religious impulses are incarnational' (italics added).

${ }^{21}$ Eric Greenberg, “Organizers Defend Cleric's Remarks” (http://njjewishnews.com/article/7031/interfaith-dialogue-hitsits-stride-on-second-day).

22 Deborah Weissman is the President of the International Council of Christians and Jews. For the other three scholars, see, e.g., Philip A. Cunningham et alii, Christ Jesus and the Jewish People Today: New Explorations of Theological Interrelationships (Grand Rapids / Cambridge: Eerdmans, 2011).

${ }^{23} 2$ Cor 12:9.
} 
of their common origin: it is not the similarities per se that bring them together but the provenance. Siblings are related in spite of possible differences and not because of similarities, as friends tend to be. ${ }^{24}$ This was pointed out by Kurt Koch's predecessor, Walter Cardinal Kasper: "...[With Nostra Aetate] we Catholics became aware with greater clarity that the faith of Israel is that of our elder brothers..."25

What can Jews and Christians learn from each other? Cardinal Koch writes that Jews remind Christians that the world has not yet been redeemed; they represent "the experience of [the] unredeemedness of the World." This is, I would say, an important observation. However, this notion is also related to a motif that has played a major role in the negative Christian perception of the Jew. The yearning to address Jews has had and still has an apocalyptic dimension. Far too often in history, the emphasis has been on the unredeemedness of the Jewish people.

So what might Christianity's contribution to Jewish thought be? Unfortunately, Cardinal Koch's next statement is not as helpful:

On the other hand, where the Christian church remains true to its divine mission, it is and remains a thorn in the flesh of Judaism, in that it bears witness to the already bestowed reconciliation of God with mankind, without which there can be no well-founded hope for redemption.

Many who are involved in dialogue would hesitate to describe this as a fruitful approach. Does he in fact mean that there is no future and no hope, even from a Jewish perspective? We ought to ask ourselves whether there might not be an alternative position that could evoke what Krister Stendahl felicitously described as "holy envy," i.e., a position that allows one to learn from other faith traditions. Holy envy comes from the discovery of something positive and delightful in the other tradition, something that can be acknowledged without being appropriated, allowing it to remain the treasure of the other. For a Christian this means a willingness to discern, recognize and celebrate something in another faith tradition without immediately baptizing it. ${ }^{26}$

I think it would have been better if the starting-point were the relation to the nations of the world. Jews understand Judaism as the religion of and for the Jewish people, as the covenant of God with the Jewish people-but what are the consequences of this understanding for the nations, for the other peoples? How does the God of Israel communicate with the peoples; what is it that God wants for and with the peoples? To pose these questions, I believe, would be a more fruitful approach.

\section{"If So, God Would Be Bigger than We Thought"}

When Krister Stendahl, the legendary Harvard professor, Dean of the Harvard Divinity School, and Bishop of Stockholm, passed away in 2008, many newspapers published extensive obituaries of him. In his article in the New York Times, Douglas Martin referred to an interview on National Public Radio, broadcast in 1996, in which Stendahl expressed hope that life existed on other planets. "If so", he said, "God would be bigger than we thought." This quotation says quite

\footnotetext{
${ }^{24}$ See, e.g., Jesper Svartvik, "Geschwisterlichkeit: Realizing That We Are Siblings," Kirche und Synagoge: Ein Votum aus luterischer Sicht (ed. Folker Siegert; Göttingen: Vandenhoeck \& Ruprecht, 2012), 315-330.

${ }^{25}$ Walter Kasper, "Address on the $37^{\text {th }}$ Anniversary of Nostra Aetate" (http://www.bc.edu/dam/files/research_sites/cjl/texts/cjrelations/resources/articles/Kasper_NA37.htm).

${ }^{26}$ See, e.g., Yehezkel Landau, "An Interview with Krister Stendahl”, Harvard Divinity Bulletin 35:1 (2007), 31. For the expression "to discern, recognize and celebrate," see Kasper, "Address on the $37^{\text {th }}$ Anniversary of Nostra Aetate."
} 
a lot about Stendahl's personality and theology. It also says something about the challenge of the theology of religions. What if there is life on other planets? According to our theology, would God be "bigger" if there were genuine and vibrant spirituality in other religious traditions? Few questions are more important to address than this one. The Cardinal's inaugural lecture poses significant questions and addresses important issues. I am most grateful for the invitation to comment on his stimulating and challenging text. I would also like to take this opportunity to wish him every success in his endeavors. To promote understanding and reconciliation between Jews and Christians is one the greatest imperatives in interreligious relations today. 